\title{
ISPITIVANJE INTERESA I ZADOVOLJSTVA NASTAVOM LIKOVNE UMJETNOSTI KAO POTICAJA ZA RAZVOJ SPOSOBNOSTI UČENJA OSTALIH NASTAVNIH PREDMETA
}

\author{
Miroslav D. Drljača ${ }^{1}$, Siniša Opićn ${ }^{2}$, Milan Matijević ${ }^{2}$ \\ ${ }^{1}$ Filozofski fakultet, Univerzitet u Banjoj Luci, Bosna i Hercegovina \\ ${ }^{2}$ Učiteljski fakultet, Sveučilište u Zagrebu, Hrvatska \\ miroslav.drljaca@ff.unibl.org; sinisa.opic@ufzg.hr; \\ milan.matijevic@ufzg.hr
}

Primljeno: 27. 1. 2020.

Istraživanje je provedeno na uzorku učenika trećih razreda strukovnih škola i gimnazija (N=605). Od uključenih učenika, gimnaziju je pohađalo njih 253, a srednje strukovne škole 352 učenika. Cilj istraživanja bio je ispitati neke specifičnosti u percepciji učenika srednjih škola o važnosti nastavnih predmeta iz područja likovnih umjetnosti. Napravljena je posebna analiza samo za dvije odabrane zavisne varijable: važnost nastavnih predmeta iz područja likovnih umjetnosti za razvoj pamćenja i sposobnosti za učenje ostalih nastavnih predmeta te interes $i$ zadovoljstvo sudjelovanjem u likovnim aktivnostima. Rezultati pokazuju da ne postoji statistički značajna razlika između učenika gimnazija i strukovnih škola u procjeni sudjelovanja u aktivnostima nastave likovne umjetnosti te u procjeni važnosti likovnih aktivnosti za razvoj pamćenja i sposobnosti za učenje ostalih predmeta. Postoji statistički značajna spolna razlika u procjeni sudjelovanja u aktivnostima nastave likovne umjetnosti te u procjeni važnosti likovnih aktivnosti za razvoj pamćenja $i$ sposobnosti za učenje ostalih predmeta. Može se zaključiti da ispitanici nisu bili u mogućnosti procijeniti koliko i u koju svrhu će im u daljnjem školovanju i budućem zanimanju koristiti kompetencije stečene u nastavi likovne umjetnosti.

Ključne riječi: gimnazija, strukovne škole, likovna kultura, nastava likovne umjetnosti, interes za likovne aktivnosti, zadovoljstvo nastavom likovne kulture 


\section{Uvod}

Do završetka dvanaest godina školovanja svaki građanin Hrvatske i država u okruženju provede na nastavnim aktivnostima oko 11000 nastavnih sati. Među tim nastavnim satima samo se oko 350 sati odnosi na likovne aktivnosti, a još približno toliko na glazbene. Izuzetno malo nastavnih aktivnosti odnosi se na one u kojima se nešto radi rukama, odnosno u kojima se uči i rukama. Kurikulumi obvezne osnovne škole dizajnirani su uglavnom na način kao da će svi nastaviti školovanje u gimnaziji, a gimnaziju je tijekom proteklih godina u Hrvatskoj upisivalo samo oko jedne četvrtine školske populacije. Jedna trećina populacije učeničke generacije upisivala je obrtničke ili zanatske škole. Ostali su upisivali razne strukovne škole. Dakle, tijekom obvezne škole nisu stjecali i kompetencije važne za nastavak školovanja u zanatskim ili obrtničkim školama.

Nastavni predmeti koji se odnose na likovne ili tehničke aktivnosti tijekom obveznog školovanja zauzimaju minoran fond nastavnih sati i aktivnosti (Drljača, 2018). Autori školskih kurikuluma kao i većina školskih stručnjaka umanjuju značenje likovno-umjetničkih aktivnosti za nastavak školovanja i pripremanje za cjeloživotno učenje i rad.

Tijekom proteklih pola stoljeća na tržištu pedagoške literature pojavilo se dosta knjiga i znanstvenih radova koji objašnjavaju novi kontekst učenja pripadnika net generacija (Gardner, 1983; Jensen, 2001; 2013; Matijević, 2017). Značajan broj tih znanstvenih radova odnosi se na spoznaje iz neuroznanosti, odnosno obrazovne neuroznanosti te teorije višestrukih inteligencija (Armstrong, 2006; Rajović, 2017). Te teorije donose nova znanstvena objašnjenja i nove metodičke smjernice za djelovanje u odgoju. Promjene pod utjecajem obrazovne neuroznanosti (Rosenberg-Lee, 2018) te teorije višestrukih inteligencija u praksi se ne događaju očekivanim intenzitetom (Jensen, 2005; Caine, Caine, 1991; Hermann, 2009; Rajović, 2013; 2017; Maras, Topolovčan, Matijević, 2018).

Dugo je u pedagoškoj praksi i teoriji poznata izreka: ne uči se samo glavom, već glavom, srcem i rukama (Heinrich Pestalozzi, krajem 18. stoljeća). I pored toga je u teoriji i praksi učenje rukama i srcem tijekom proteklog stoljeća bilo marginalizirano što je imalo znatan utjecaj na školske kurikulume i ishode školskog učenja. Posljedice te marginali- 
zacije osjećaju se i danas, poglavito pri izboru srednjih škola u kojima je važan rad rukama, dizajn ili umjetničko izražavanje.

Ne postoji dijete koje ne voli učiti, napose eksperimentirati rukama u okruženju gdje provodi najviše dnevnog vremena (Matijević, 2017). To eksperimentiranje rukama te emocijama i umom znatno utječe na sve vidove djetetova učenja. Interes i zadovoljstvo djece takvim aktivnostima tijesno su povezani s pamćenjem i učenjem u svim područjima života, rada i učenja.

\section{Teorijski okvir i polazišta rada}

Psihologijska istraživanja pokazala su da se lakše uči i pamti ono za što subjekti koji uče imaju određeni interes. Učenje je aktivnost u kojoj je važno zadovoljstvo subjekata koji u toj aktivnosti sudjeluju. Sposobnost za učenje složena je kompetencija koja se stječe i razvija tijekom školovanja. Iz tog je razloga za pedagoge i psihologe oduvijek važno istraživati zadovoljstvo učenika, a ono nije jednako i zadovoljavajuće $u$ nastavi svih nastavnih predmeta te u didaktičkim scenarijima koje nude svi nastavnici. Oduvijek su nastavni predmeti u kojima se od učenika traže raznovrsne aktivnosti izazivali veći interes i zadovoljstvo kod učenika u odnosu na nastavne predmete u kojima se mnogo sjedi, sluša i gleda. Među takve nastavne predmete svakako spadaju svi umjetnički predmeti te tjelesni odgoj, kao i svi predmeti u kojima se traže fizičke aktivnosti (Baureis, 2015; Kuščević, Brajčić, Mišurec, 2009; Mathewson Mitchell, 2015; Matijević, Drljača, Topolovčan, 2016a; 2016b, Barjaktarov, Opačić, 2018; Drljača, 2018).

Još su predstavnici pravaca reformske pedagogije, napose Montessori i Steiner, upozoravali na važnost aktivnosti rukama za učenje u svim ostalim područjima, a broj onih koji ukazuju na važnost umjetničkog odgoja za učenje porastao je krajem proteklog i tijekom ovog stoljeća (Jensen, 2001; 2003; 2005; Carlgren, 1992; Philips-Reichherzer, 2003). Posebno su važna znanstvena upozorenja o utjecaju vizualnih umjetnosti na poboljšanje učenja čitanja i matematike (Gardiner, 1996; prema Jensen, 2001, 159), a cjelovito gledanje na ulogu umjetnosti na učenje u općeobrazovnim školama u svojim radovima iznosi Jensen (2001; 2003; 2005). 
Kako je rečeno, nužnost holističkog gledanja na učenje glavom, srcem i rukama uočili su već predstavnici projekata reformske pedagogije, početkom proteklog stoljeća. U isticanju važnosti učenja rukama i umjetničkog odgoja za cjelovito obrazovanje posebno se tada ističu Marija Montessori, Rudolf Steiner, Celestin Freinet, Peter Petersen te Georg Kerschensteiner i Hugo Gaudig (Topolovčan, Rajić, Matijević, 2017). Maria Montessori cjelokupni svoj pedagoški koncept bazira na radu rukama koristeći raznovrsni materijal i predmete (Montessori, 1988). Ta pedagoška koncepcija i danas ima tisuće pristaša i zagovornika. Najdalje je u isticanju važnosti umjetnosti i učenja rukama tijekom pokreta reformske pedagogije otišao Rudolf Steiner (1995a; 1995b), a i danas ovaj pedagog, antropozof, makrobiotičar i teozof privlači veliki broj učitelja i roditelja (Steiner, 1995a; 1995b; Wiel, 2019; Steiner, 1919; Frielingsdorf, 2019; Skiera, 2010). U školskim kurikulumima waldorfskih škola nađe se dovoljno mjesta za učenje glavom, srcem i rukama, odnosno za učenje kognitivnih, afektivnih i motoričkih kompetencija te za učenje kognitivnih, radnih i tehničkih te umjetničkih kompetencija. Pedagoški modeli Rudolfa Steinera i Marije Montessori mogli bi poslužiti kao primjeri kako dizajnirati školski kurikulum koji uvažava teoriju višestrukih inteligencija i spoznaje obrazovne neuroznanosti. Komparativnih istraživanja koja propituju prednosti i nedostatke Montesosori i Steinerova pedagoškog modela vrlo je malo. Bilo bi korisno više takvih istraživanja, kao i komparativnih istraživanja didaktike u Montessori, Steinerovim i javnim školama (Seitz, Hallwachs, 1977; Skiera, 2010).

U mnogim državama uočen je problem marginalizacije umjetničkog obrazovanja u općeobrazovnim školama pa se organiziraju različiti istraživački projekti evaluacije postojećih oblika realizacije programa umjetničkog odgoja (Mathewson Mitchell, 2015; Mullen, Wolff, 2018; Nkem, Femi, 2018; Herzog, 2018; Kovačević, 2011). Znanstvena proučavanja važnosti i djelotvornosti umjetničkog odgoja u Australiji također su predmetom interesa znanstvenika. Jedna od istaknutih znanstvenica u tome području, Donna Mathewson Mitchell (2015), predvodi skupinu istraživača vizualne umjetnosti u srednjim školama Australije. Njezino je trenutno istraživanje usredotočeno na nastavnu praksu likovne umjetnosti, obrazovanje učitelja te poučavanje i učenje u javnim školama. Rezultat su nova teorijska načela za metodološki dizajn nastave umjetnosti u srednjim školama. Svrha je doći do novih modela pou- 
čavanja umjetnosti, primjerenijeg novim generacijama učenika srednjih škola (Mathewson Mitchell, 2015). U SAD je tijekom 2018. godine doneseno više od 1400 novih državnih zakona koji se odnose na obrazovne politike. Izvješće o trendovima obrazovanja (Mullen, Wolff, 2018) istražuje i područja obrazovne politike koja se odnosi na umjetnost u obrazovnim djelatnostima i odgovornim sudionicima za to područje. Propituje se može li se proširiti mogućnosti uključivanja umjetnosti u politička rješenja važnih pitanja u obrazovanju. Istaknuti su i primjeri kako država trenutno koristi umjetnost u području obrazovanja (Mullen, Wolff, 2018). U Nigeriji je organiziran istraživački projekt s reprezentativnim uzorkom učitelja i učenika višeg srednjeg obrazovanja, a u svezi evaluacije ostvarivanja ciljeva umjetničkog odgoja. Nalazi istraživanja pokazuju da su, iako su postignuti neki ciljevi umjetničkog odgoja, uočeni loša izvedba, neprimjerenost infrastrukturnih objekata te velike manjkavosti nastavnih materijala (Nkem, Femi, 2018).

Slovenska likovna pedagoginja Jerneja Herzog (2018) smatra da razvijanje kreativnosti u osnovnoj školi ne može biti zadatak samo predmeta likovne kulture nego svih nastavnih predmeta. Svi nastavni predmeti trebaju, dakle, poticati učenike na kreativno izražavanje. U svome radu autorica predstavlja rezultate istraživanja u kojemu je analizirana razina likovnog razvoja kod učenika četvrtih razreda osnovnih škola u Hrvatskoj. Rezultati pokazuju da su dječaci općenito kreativniji, ali da su djevojčice ipak uspješnije u optičko-tematskom razvoju (Herzog, 2018). Hrvatski pedagog koji se bavi tehničkom kulturom, Stjepan Kovačević, razmatrao je teleološku i pragmatičku povezanost umjetničkog i tehničkog područja odgoja i općeg obrazovanja (Kovačević, 2011). Pri ovoj analizi autor uzima europsku tradiciju nastavnog predmeta zanatstvo (engl. craft) u kojemu su didaktički utjelovljeni umjetnost i tehnika. Istraživanjem provedenim na prigodnom uzorku osnovnoškolaca ustanovljena je statistički značajna pozitivna korelacija između uspjeha koji postižu u tehničkoj i likovnoj kulturi. Ta povezanost interpretirana je kao potreba integriranog pristupa programiranju umjetnosti i tehnike (Kovačević, 2011). Marija Brajčić (2016) kritički propituje mjesto umjetnosti u školskim kurikulumima. U svome radu autorica ističe bitne zaključke o obrazovnom sustavu te o nekim netradicionalnim pristupima nastavom kurikulumu. Analiza pokazuje na često evidentno zanemarivanje mjesta umjetnosti u školskim kurikulumima (Brajčić, 2016). 
Pri objašnjavanju tih činjenica valja imati na umu društvene, političke i ekonomske uvjete koji su važni za odnos umjetnosti i obrazovanja te mjesto umjetnosti u obrazovnim kurikulumima.

Drljača, Opić i Matijević (2020) bavili su se mjestom likovne umjetnosti u kontekstu općeg obrazovanja u strukovnim školama i gimnazijama te odnosom umjetnosti prema ostalim sastavnicama općeg obrazovanja. Cilj je bio ispitati kako učenici višeg sekundarnog obrazovanja procjenjuju važnost nastavnih predmeta iz područja likovnih umjetnosti za stjecanje znanja iz opće kulture te važnost likovne kulture za njihovo buduće zanimanje. Ispitanici $(\mathrm{N}=605)$ su bili učenici trećeg razreda višeg sekundarnog obrazovanja. Za istraživanje je konstruiran upitnik s 50 zavisnih varijabli. Iako ispitanici iz uzorka ne pridaju važnost predmetima likovne kulture za buduća zanimanja, ipak su procijenili da su im tijekom školovanja aktivnosti za koje je bio potreban rad rukama donekle pomogle u razvoju pamćenja i sposobnosti za učenje ostalih predmeta. Vrsta škole kao statistički značajni prediktor ukazuje na to da učenici strukovne škole više od svojih kolega gimnazijalaca važnima smatraju likovne umjetnosti za strukovna zanimanja. Učenici pridaju najmanju važnost likovnoj kulturi u izvršavanju zadataka iz stranog jezika, a najveću za tehničku kulturu. Rezultati ukazuju na potrebu davanja većeg značaja i više vremena likovnoj kulturi u nastavnim kurikulumima općeobrazovnih i strukovnih škola (Drljača, Opić, Matijević, 2020).

\section{Istraživanje}

\section{Cilj i hipoteze}

Cilj je istraživanja bio ispitati neke specifičnosti u percepciji učenika srednjih škola o važnosti nastavnih predmeta iz područja likovnih umjetnosti za razvoj pamćenja i sposobnosti za učenje ostalih nastavnih predmeta te dobiti uvid o njihovu interesu i zadovoljstvu sudjelovanjem u likovnim aktivnostima tijekom školovanja.

Sukladno cilju istraživanja postavljene su sljedeće hipoteze: H1 - Postoji statistički značajna razlika između učenika gimnazije i strukovne škole u procjeni interesa i zadovoljstva aktivnostima 
nastave likovne umjetnosti te o procjeni važnosti likovnih aktivnosti za razvoj pamćenja i sposobnosti za učenje ostalih predmeta.

$\mathrm{H} 2$ - Postoji statistički značajna spolna razlika u procjeni interesa i zadovoljstva aktivnostima nastave likovne umjetnosti te o važnosti likovnih aktivnosti za razvoj pamćenja i sposobnosti za učenje ostalih predmeta.

H3 - Postoji statistički značajna povezanost između školskog uspjeha učenika i njihove procjene interesa i zadovoljstva aktivnostima nastave likovne umjetnosti te o važnosti likovnih aktivnosti za razvoj pamćenja i sposobnosti za učenje ostalih predmeta.

\section{Populacija i uzorak}

Ovo istraživanje i statistička izračunavanja izvršeni su na istom uzorku kao i u radu autora Drljača, Opić i Matijević (2020). Dakle, ispitanici ( $\mathrm{N}=605)$ su učenici trećeg razreda strukovnih škola i gimnazija iz sjevernog područja Bosne i Hercegovine te iz središnje Hrvatske. Ispitanici su izabrani iz devet škola koje se nalaze u šest gradova Republike Hrvatske i tri grada Republike Bosne i Hercegovine. Izabran je treći razred srednje škole (više sekundarno obrazovanje) zato što su svi imali tijekom prethodnog školovanja neki predmet iz područja likovnih umjetnosti, dakle tijekom obvezne osnovne i prva dva razreda srednje škole. Radi se o uzorku skupina koji ima obilježja i hotimičnog uzorka jer su namjerno odabrane dvije države i srednje škole iz kojih su ravnatelji ili školski stručni suradnici izrazili želju za sudjelovanjem. Iz BiH ispitano je 240 ispitanika, a iz Hrvatske 400 ispitanika. Od ispitanih učenika gimnaziju je pohađalo 253 ispitanika, a srednje strukovne škole 352 ispitanika. Ispitanici iz strukovnih škola pohađali su jedanaest različitih programa.

\section{Instrument i postupak}

$\mathrm{Za}$ ispitivanje je korišten upitnik koji udovoljava logici cilja, problema i hipoteza te zavisnih i nezavisnih varijabli, a koji su za spomenuto prethodno istraživanje izradili i koristili Drljača, Opić i Matijević (2020). Iz spomenutog šireg istraživanja na temu odnosa učenja u likovnim aktivnostima s ostalim nastavnim predmetima za potrebu 
ovoga rada izdvojena je analiza za dvije odabrane zavisne varijable: važnost nastavnih predmeta iz područja likovnih umjetnosti za razvoj pamćenja i sposobnosti za učenje ostalih nastavnih predmeta te interes i zadovoljstvo sudjelovanjem u likovnim aktivnostima tijekom obveznoga školovanja. Za odgovore su primijenjene grafičke skale od pet stupnjeva, od 1 do 5 , pri čemu je 1 predstavljala najnižu, a 5 najvišu vrijednost. Nezavisne varijable odnose se na pripadnost ispitanika određenom poduzorku s obzirom na državu, vrstu srednje škole te spol ispitanika i prosječnu ocjenu prethodno završenog razreda.

Kao u radu Drljača, Opić i Matijević (2020), i ovdje smo se odlučili za kvantitativnu metodologiju istraživanja s neeksperimentalnim diferencijalnim i korelacijskim nacrtom empirijskog istraživanja. Osim deskriptivne analize (MCT, MV, obilježja sampling distribucija), korišteni su testovi u području inferencijalne statistike; t test za nezavisne uzorke (u bootstrapped modelu) te Pearson koeficijent bivarijatnih korelacija. Prikupljanje podataka provedeno je u studenom i prosincu 2018. godine. Učenike smo, uz suglasnosti uprave škola, anketirali tijekom jednog školskog sata, odnosno u trajanju od 30 minuta.

\section{Rezultati i rasprava}

Osnovne deskriptivne vrijednosti zavisnih varijabli prikazane su u Tablici 1.

Tablica 1. Deskriptivne vrijednosti zavisnih varijabli

\begin{tabular}{|c|c|c|c|c|c|c|c|c|c|c|}
\hline \multirow{2}{*}{$\frac{\stackrel{0}{0}}{: \frac{\pi}{\vec{n}}}$} & \multirow{2}{*}{ 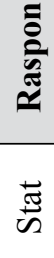 } & \multirow{2}{*}{ 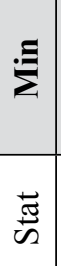 } & \multirow{2}{*}{ 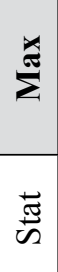 } & \multicolumn{2}{|c|}{ Arit.sred. } & \multirow{2}{*}{$\begin{array}{c}\text { Std. } \\
\text { Dev. }\end{array}$} & \multicolumn{2}{|c|}{$\begin{array}{l}\text { Asimetrija } \\
\text { (Skewness) }\end{array}$} & \multicolumn{2}{|c|}{$\begin{array}{l}\text { Spljoštenost } \\
\text { (Kurtosis) }\end{array}$} \\
\hline & & & & $\stackrel{\vec{\pi}}{\tilde{\omega}}$ & 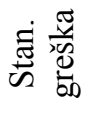 & & $\stackrel{\vec{E}}{\tilde{\omega}}$ & 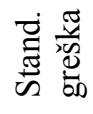 & $\stackrel{\vec{\pi}}{\omega}$ & 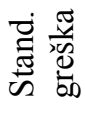 \\
\hline 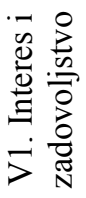 & 4 & 1 & 5 & 3,31 & ,053 & 1,30 &,- 356 & ,099 & 882, & , 198 \\
\hline
\end{tabular}




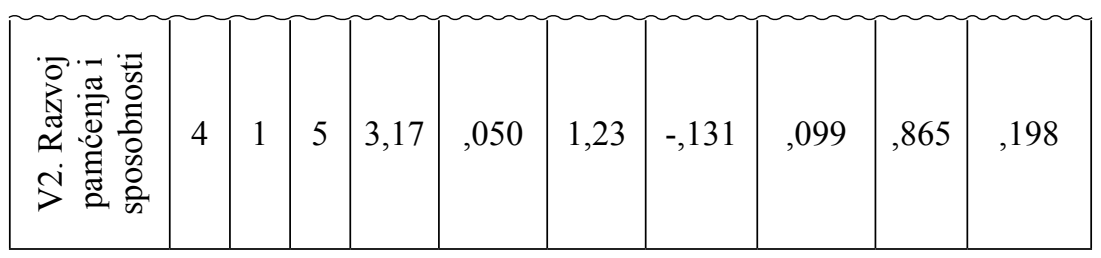

Legenda: V1: interes i zadovoljstvo sudjelovanjem u likovnim aktivnostima tijekom obveznoga školovanja; V2: važnost nastavnih predmeta iz područja likovnih umjetnosti za razvoj pamćenja i sposobnosti za učenje ostalih nastavnih predmeta

Kao što je vidljivo iz Tablice 1 (usp. i Slika 1), obje zavisne varijable imaju blago povišene vrijednosti AS-a (usporedo i položajne mjere MCT-a; Mod=3, Medijan=3). Riječ je o blago lijevo asimetričnim sampling distribucijama, a sukladno smjeru skale i vrijednosti MCT-a. Također obje varijable su blago platikurtične (usporedo $\mathrm{Cv}_{(\mathrm{vl})}=39,4 \%$; $\mathrm{Cv}(\mathrm{v} 2)=39,06 \%$ ). Raspon odgovora je maksimalan što indicira da varijable dobro pokrivaju spektar mogućih odgovora - od krajnje negativnog do krajnje pozitivnog stava prema aktivnostima nastave likovne umjetnosti.

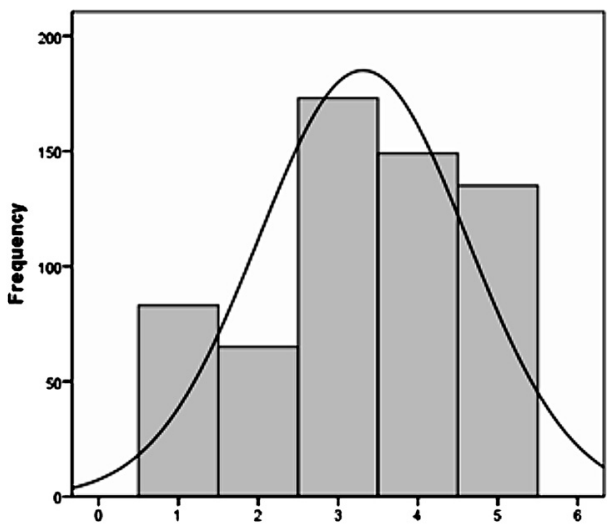

Slika 1. Procjena interesa i zadovoljstva aktivnostima nastave likovne umjetnosti (V1) 


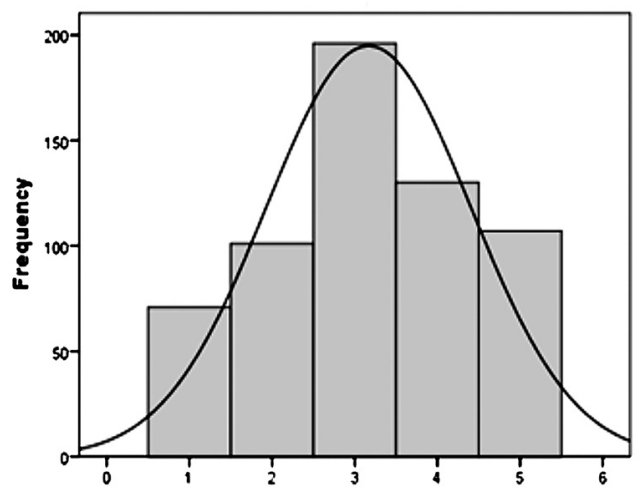

Slika 2. Važnosti likovnih aktivnosti za razvoj pamćenja i sposobnosti za učenje ostalih predmeta (V2)

Za testiranje $\mathrm{H} 1$ korišten je parametrijski t test za nezavisne uzorke u bootstrapped modelu. Distribucija nezavisne varijable je: gimnazija $(253,41,8 \%)$, strukovna škola $(352,58,22 \%)$. Rezultati t-testa prikazani su u Tablici 2a i Tablici 2b.

Kao što je vidljivo iz tablica $2 \mathrm{a}$ i $2 \mathrm{~b}$, ne postoji statistički značajna razlika između učenika gimnazije i strukovne škole u procjeni interesa i zadovoljstva aktivnostima (V1) nastave likovne umjetnosti te u procjeni važnosti likovnih aktivnosti za razvoj pamćenja i sposobnosti (V2) za učenje ostalih predmeta. Takav rezultat je zapravo iznenađujući, štoviše ohrabrujući jer ukazuje da se nastava likovne umjetnosti izvodi kvalitetno u različitim vrstama škola. Možda interes učenika za nastavu likovne umjetnosti, kao i zadovoljstvo i procjena važnosti za razvoj pamćenja i sposobnosti primarno proizlazi iz osnovne škole, ali također i iz srednje škole. Očekivali smo da će učenici gimnazije procijeniti veći interes i zadovoljstvo likovnim aktivnostima s obzirom na gimnazijski nastavni plan i program te zbog potencijalnog visokoškolskog obrazovanja, no tomu nije tako. Dakle, bez obzira na izrazito različite planove i programe gimnazija i strukovnih škola, za nastavu likovne umjetnosti im je zajednički interes i zadovoljstvo. Time se odbacuje H1. 


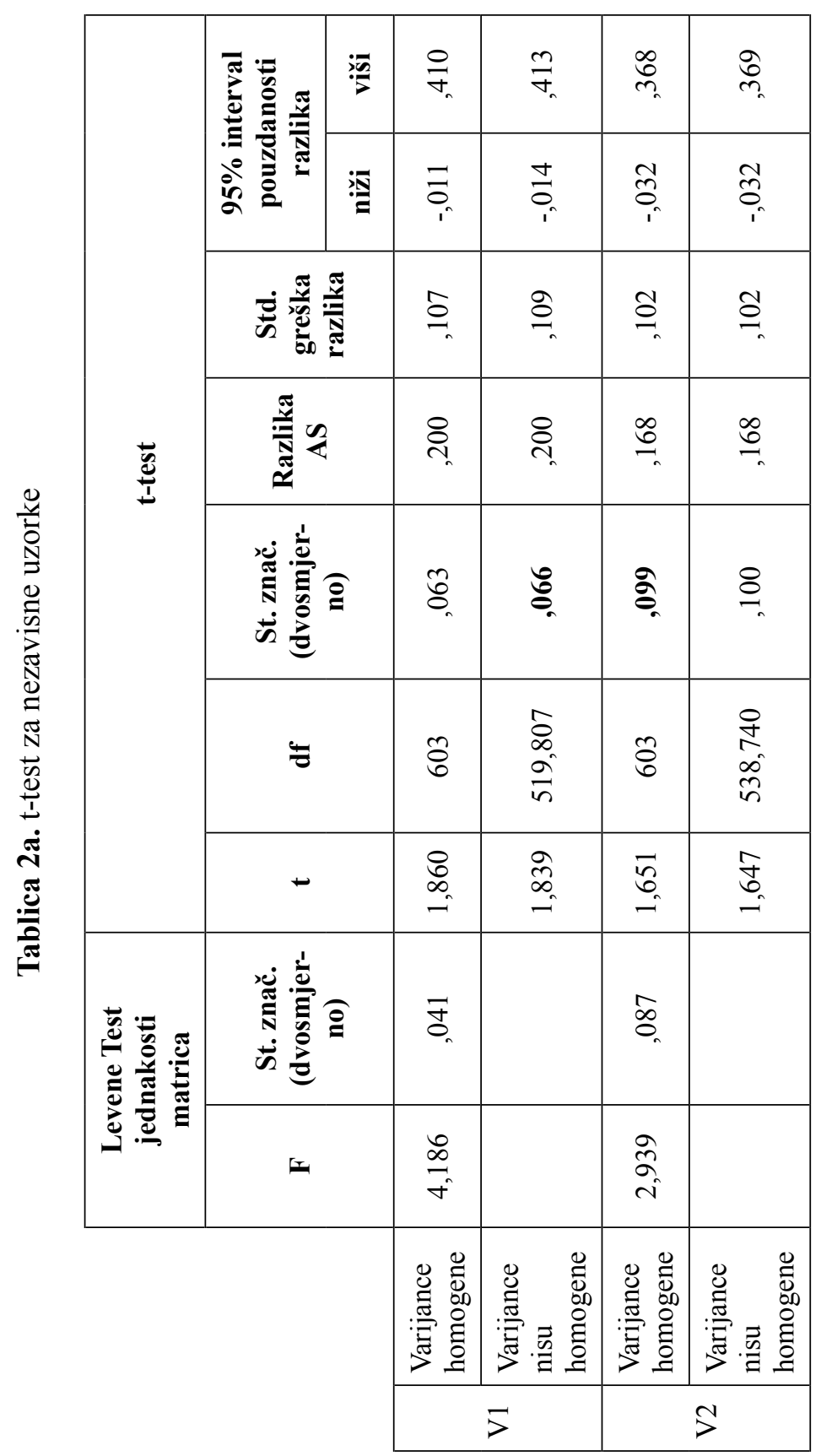




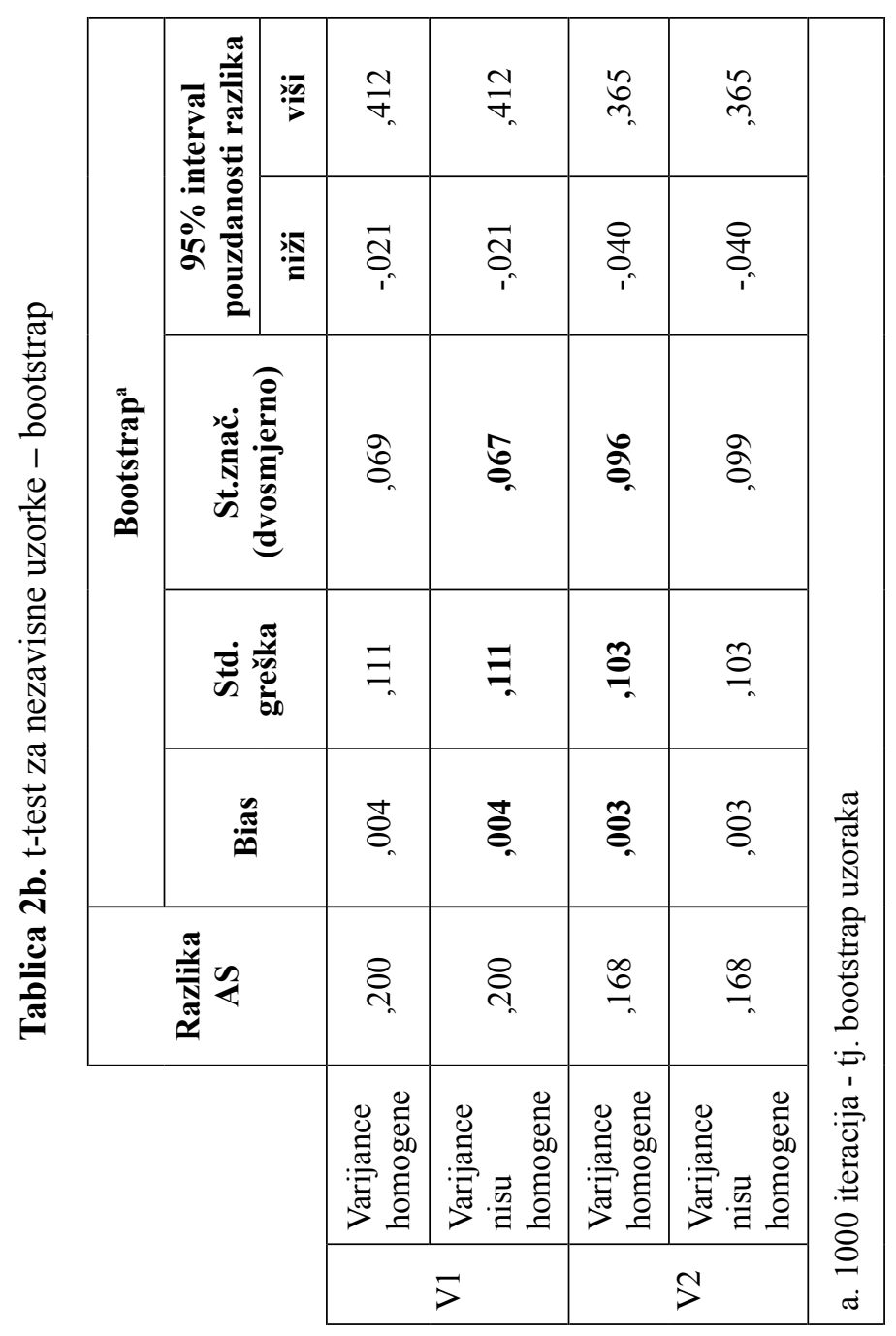


Za testiranje $\mathrm{H} 2$ korišten je parametrijski t-test za nezavisne uzorke u bootstrapped modelu. Bootstrapped model primijenjen je zbog disproporcije subuzoraka, iako je homogenost varijanci subuzoraka na zavisnim varijablama ispunjena (homoscedascitet). Distribucija nezavisne varijable spol je: muški (235, 38,8 \%), ženski (370, 61,2 \%). Rezultati t-testa prikazani su u tablicama 3a i $3 b$.

Kao što je vidljivo u tablicama 3a i 3b, postoji statistički značajna spolna razlika u procjeni interesa i zadovoljstva sudjelovanjem u aktivnostima nastave likovne umjetnosti te u procjeni važnosti likovnih aktivnosti za razvoj pamćenja i sposobnosti za učenje ostalih predmeta. Iz vrijednosti AS (V1: mean $_{\text {men }}=3.02$; mean $_{\text {women }}=3.50 ; \mathrm{V} 2$ : mean $_{\text {men }}=2.86 ;$ mean $_{\text {women }}=3.36$ (usporedo mean difference) očigledno učenice više od učenika procjenjuju važnost nastave likovne umjetnosti. Takav rezultat smo i očekivali jer učenice općenito postižu viši uspjeh u školi, što je i u ovom istraživanju slučaj $\left(\mathrm{AS}_{\text {učenice }}=4.11, \mathrm{AS}_{\text {učenici }}=3.83\right)$. Budući da postižu bolji uspjeh u školi, procijenile su i veći interes i zadovoljstvo nastavom likovne umjetnosti od svojih kolega učenika. Time se potvrđuje $\mathrm{H} 2$.

Za testiranje $\mathrm{H3}$ u području bivarijatnog korelacijskog nacrta istraživanja korišten je Pearsonov koeficijent korelacije u bootstrapped modelu. Distribucija varijable školski uspjeh je dovoljan $5(1 \%)$, dobar $116(23,9 \%)$, vrlo dobar $236(48,6 \%)$ te odličan 129 (26,5\%). Rezultati su prikazani u Tablici 4. 


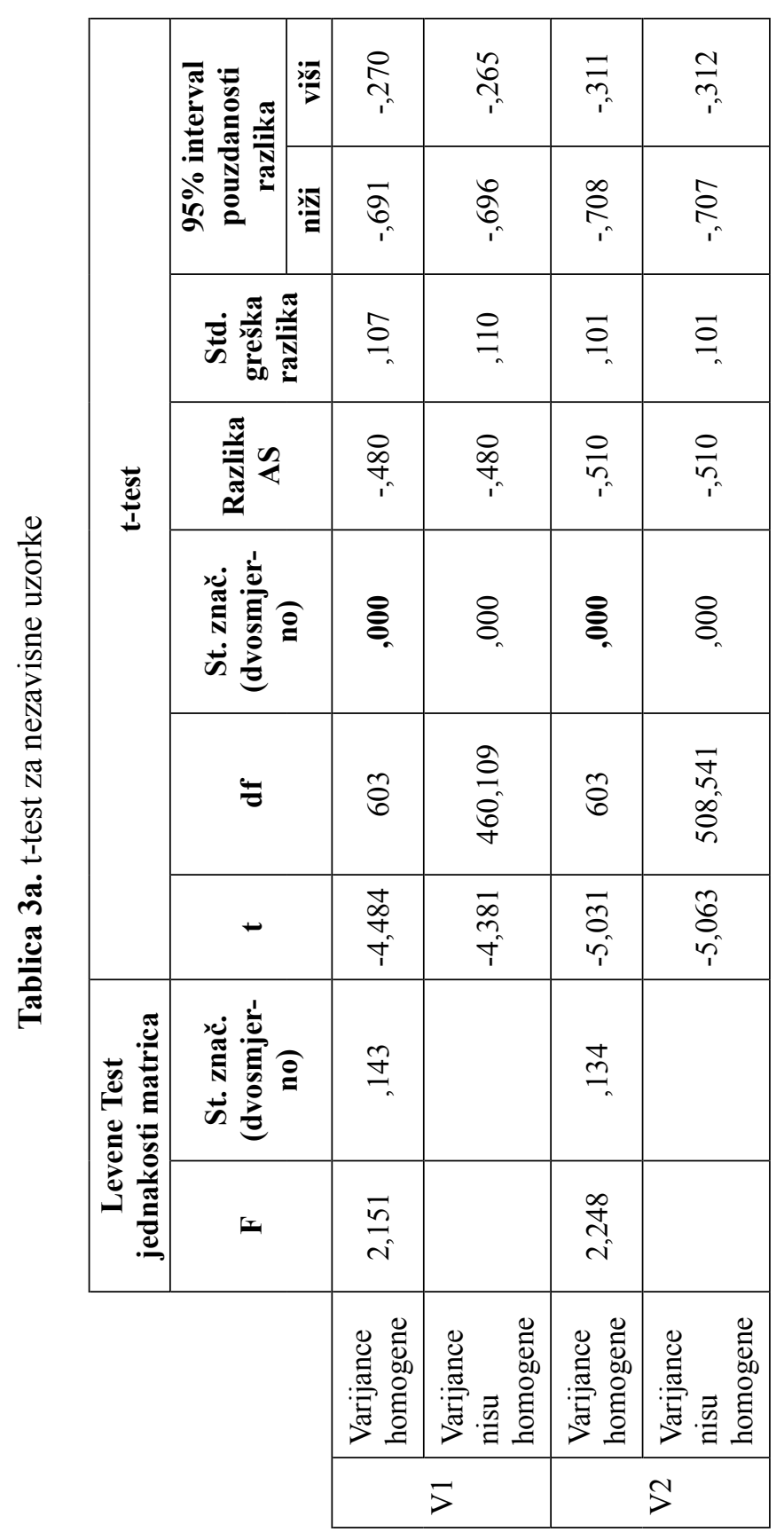




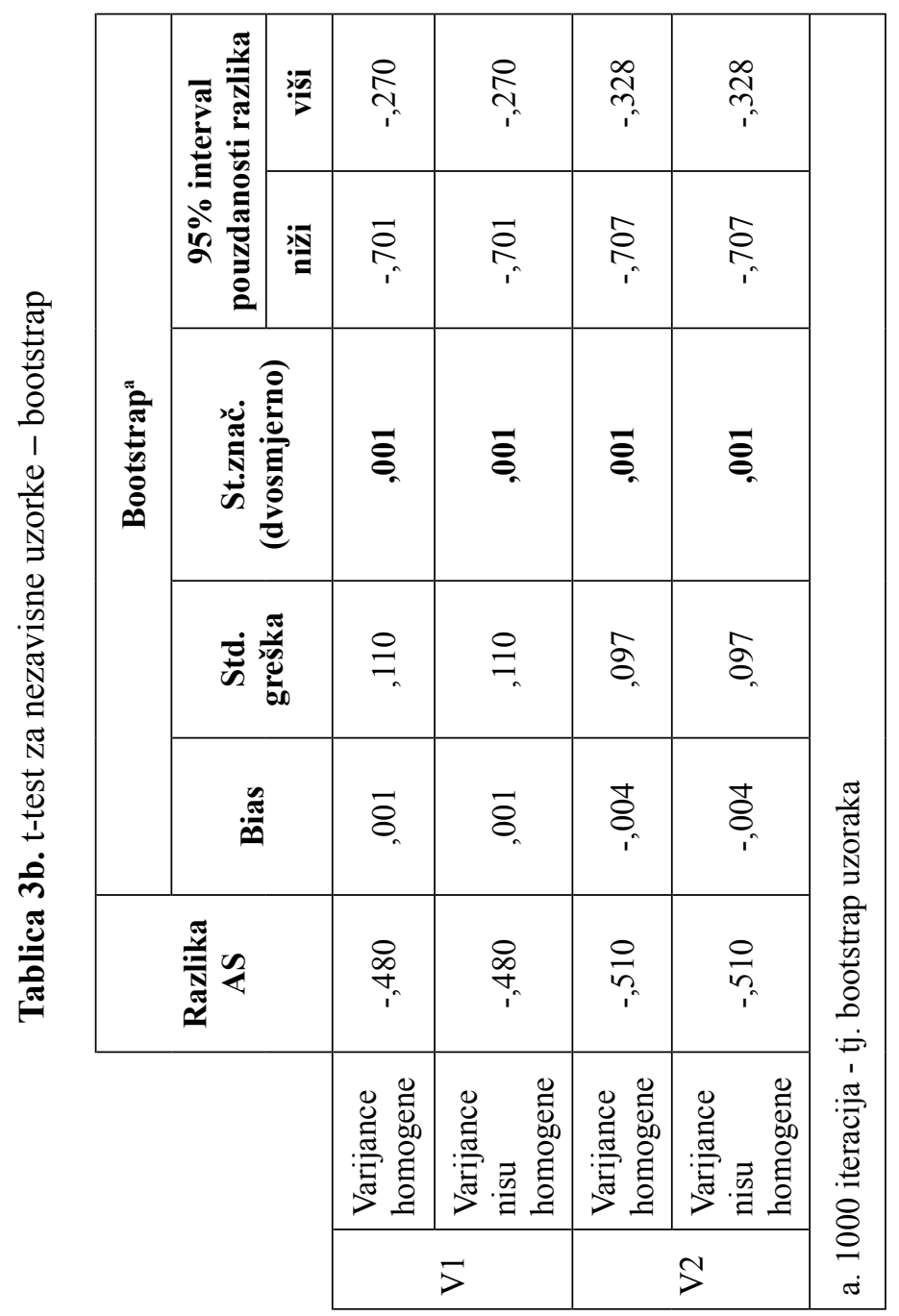


Tablica 4. Korelacije

\begin{tabular}{|c|c|c|c|c|c|}
\hline & \multirow{3}{*}{$\begin{array}{c}\mathbf{V 1} \\
, 054\end{array}$} & \multirow{3}{*}{$\begin{array}{l}\text { V2 } \\
, 040\end{array}$} \\
\hline & & & & & \\
\hline \multirow{7}{*}{ Prosjek } & \multicolumn{3}{|c|}{ Pearsonov koeficijent korelacije } & & \\
\hline & \multicolumn{3}{|c|}{ St.značajnost (dvosmjerno) } & 237 & 373 \\
\hline & \multicolumn{3}{|c|}{$\mathrm{N}$} & 486 & 486 \\
\hline & \multicolumn{3}{|c|}{ Bias } & 000 &,- 005 \\
\hline & \multirow{3}{*}{ Bootstrap } & \multicolumn{2}{|c|}{ Std. greška } & 043 & 047 \\
\hline & & \multirow{2}{*}{$\begin{array}{l}95 \% \text { interval } \\
\text { pouzdanosti }\end{array}$} & niži &,- 030 &,- 057 \\
\hline & & & viši & ,138 & 132 \\
\hline
\end{tabular}

Kao što je vidljivo iz Tablice 4, ne postoji statistički značajna povezanost između školskog uspjeha učenika i njihove procjene sudjelovanja u aktivnostima nastave likovne umjetnosti te u procjeni važnosti likovnih aktivnosti za razvoj pamćenja i sposobnosti za učenje ostalih predmeta. Iako je u prethodnoj hipotezi potvrđeno da učenice više od učenika pridodaju važnost nastavi likovne umjetnosti te postižu viši školski uspjeh, općenito školski uspjeh nema važnu ulogu u procjeni zadovoljstva i interesa za nastavu likovne umjetnosti te u procjeni važnosti za razvoj pamćenja i sposobnosti. Očekivali smo da učenici koji postižu viši školski uspjeh veću važnost pridodaju nastavi likovne umjetnosti. No, tomu nije tako. Možemo zaključiti da nastava likovne umjetnosti ravnomjerno ima značaj za sve učenike. Time se odbacuje H3.

\section{Zaključci}

U svijetu raste interes za istraživanje i vrednovanje nastave likovne umjetnosti u obrazovanju i školstvu. Evo nekih osnovnih rezultata koje smo prethodno citirali prikazujući reprezentativna istraživanja o ovoj temi. Istraživanja su pokazala veliku dobrobit likovnog stvaralaštva (Šarančić, 2014), jednako i za učenike s poteškoćama u razvoju (Herzog, Serec, 2016). Značajni su rezultati dobiveni praćenjem likovnog razvoja učenika primarnog obrazovanja na primjeru škola u Hrvatskoj (Herzog, 2018). Korisno je uključivanje umjetnosti u širi kontekst obrazovne politike i utjecaj nastave likovne umjetnosti na važne trendove u obrazovanju (Mullen, Wolff, 2018). Važna je i evaluacija ciljeva pro- 
grama likovnog obrazovanja u Nigeriji (Nkem, Femi, 2018). Potraga za kvalitetom u obrazovanju učitelja u Turskoj ide kroz širenje programa osposobljavanja nastavnika likovnog obrazovanja u srednjoškolskom obrazovanju (Sanal, Ozen, 2018). Odrasli ne poznaju i ne razumiju dje$\mathrm{cu}$ - roditelje i učitelje treba poučavati o djeci i djetinjstvu kako bi ih više voljeli i bolje odgajali (Steiner, 2019). Mnogo se može naučiti iz pokreta i pravaca reformske pedagogije. Rad i umjetnost čine suštinu odgoja i obrazovanja oslanjanjem na razne medije. Waldorfska i Montessori škola pružaju dobra objašnjenja i oslonce za radni i umjetnički odgoj. Slobodne alternativne škole te odgoj u slobodi daju velike šanse za organizaciju odgoja koji stvara uvjete za optimalan razvoj mlade ljudske jedinke (Skiera, 2010).

Nakon testiranja hipoteza koje se odnose na učenike gimnazije i strukovne škole $u$ procjeni sudjelovanja $u$ aktivnostima nastave likovne umjetnosti te o procjeni važnosti likovnih aktivnosti za razvoj pamćenja i sposobnosti za učenje ostalih predmeta došli smo do korisnih zaključaka. Raspon odgovora na zavisnim varijablama je maksimalan što indicira da varijable dobro pokrivaju spektar mogućih odgovora od krajnje negativnog do krajnje pozitivnog stava prema aktivnostima nastave likovne umjetnosti.

Rezultati inferencijalne statistike ukazuju da ne postoji statistički značajna razlika između učenika gimnazije i strukovne škole u procjeni sudjelovanja u aktivnostima nastave likovne umjetnosti te u procjeni važnosti likovnih aktivnosti za razvoj pamćenja i sposobnosti za učenje ostalih predmeta. Sukladno drugoj hipotezi potvrđuje se statistički značajna spolna razlika u procjeni sudjelovanja u aktivnostima nastave likovne umjetnosti te u procjeni važnosti likovnih aktivnosti za razvoj pamćenja i sposobnosti za učenje ostalih predmeta. Iz vrijednosti AS očigledno učenice više od učenika cijene važnost nastave likovne umjetnosti u nastavnim kurikulumima.

H3 hipotezom potvrđeno je da ne postoji statistički značajna povezanost između školskog uspjeha učenika i njihove procjene sudjelovanja u aktivnostima nastave likovne umjetnosti te u procjeni važnosti likovnih aktivnosti za razvoj pamćenja i sposobnosti za učenje ostalih predmeta. Zaključiti možemo da svi nastavnici srednjih škola, pa čak i nastavnici likovne kulture, ne rade na afirmaciji značaja likovnih aktivnosti u cjelini nastavnog kurikuluma i holističkom razvoju učenika 
srednjih škola. Dakle, skromna satnica i likovni resursi ne koriste se optimalno za cjeloviti razvoj učenika srednjih škola te isticanje važnosti nastavnih predmeta iz područja likovnih umjetnosti za buduća zanimanja i poslove koje će učenici obavljati nakon školovanja. Niti učenici gimnazija niti učenici strukovnih škola, uz nastavu likovne umjetnosti u kojoj su sudjelovali tijekom školovanja, nisu u stanju procijeniti koliko i za što će im u daljnjem školovanju i budućem zanimanju koristiti kompetencije stečene u nastavi likovne umjetnosti.

\section{Literatura}

Armstrong, Thomas (2006), Višestruke inteligencije u razredu, Zagreb: Educa.

Baureis, Helga (2015), Djeca bolje uče uz kineziologiju, Split: Harfa.

Brajčić, Marija (2016), »Umjetnost i obrazovanje«, Zbornik radova Filozofskog fakulteta u Splitu, 5(6-7), str. 103-126.

Caine, Renate Numela; Caine, Geoffrey (1991), Making connections: Teaching and the human brain, Alexandria, VA: Association for Supervision and $\mathrm{Cu}-$ rriculum Development.

Carlgren, Frans (1992), Odgoj ka slobodi, Zagreb: Društvo za waldorfsku pedagogiju.

Drljača, Miroslav D. (2018), Konstruktivistička nastava likovne kulture, Laktaši: Grafomark.

Drljača, Miroslav D.; Opić, Siniša; Matijević, Milan (2020), »Students' perceptions of the importance of art content and activities in schools of general education and vocational schools in Croatia and Bosnia and Hercegovina«, Revija za elementarno izobraževanje, 13(1), str. 56-68.

Frielingsdorf, Volker (2019), Geschichte der Waldorfpädagogik: Von ihrem Ursprung bis zur Gegenwart, Weinheim: Beltz Juventa.

Gardner, Howard (1983), Frames of Mind: The Theory of Multiple Inteligences, New York: Basic Books.

Herrmann, Ulrich (ur.) (2009), Neurodidaktik: Grundlagen und Vorschläge für gehirngerechtes Lehren und Lernen, Weinheim und Basel: Beltz Verlag.

Herzog, Jerneja (2018), »Monitoring the artistic development of fourth-year students. An analysis of the situation in Croatian primary schools«, Croatian Journal of Education, 20(3), str. 973-1000. doi: https://doi.org/10.15516/cje. v20i3.3041

Herzog, Jerneja; Serec, Saša (2016), »Likovna kultura u razrednoj nastavi s aspekta prilagođavanja učenika s poteškoćama u razvoju«, Život $i$ škola, 62(3), str. 231-243. 
Jensen, Eric (2001), Arts with the Brain in Mind, Alexandria, Virginia USA: Association for Supervision and Curriculum Development.

Jensen, Eric (2003), Super nastava (Super teaching), Zagreb: Educa.

Jensen, Eric (2005), Poučavanje s mozgom na umu, Zagreb: Educa.

Kovačević, Stjepan (2011), »Kurikulumske perspektive umjetnosti, tehnike i zanatstva«, Školski vjesnik, 60(4), str. 493-510.

Kuščević, Dubravka; Brajčić, Marija; Mišurec, Zorica (2009), »Stavovi učenika osmih razreda osnovne škole o nastavnom predmetu Likovna kultura«, Školski vjesnik, 58(2), str. 189-198.

Maras, Nevenka; Topolovčan, Tomislav; Matijević, Milan (2018), »Konstruktivistička didaktika i neurodidaktika u diskursu reformne pedagogije: Teorijska polazišta, dileme i komparacija«, Nova prisutnost, 16(3), str. 561-577. doi: https://doi.org/10.31192/np.16.3.9

Mathewson Mitchell, Donna (2015), »Examining practice in secondary visual arts education«, International Journal of Education \& the Arts, 16(17), 16 p. ERIC Number: EJ1081845. Dostupno na: https://files.eric.ed.gov/fulltext/ EJ1081845.pdf.

Matijević, Milan (ur.) (2017), Nastava i škola za net generacije, Zagreb: Učiteljski fakultet Sveučilišta u Zagrebu.

Matijević, Milan; Drljača, Miroslav; Topolovčan, Tomislav (2016a), »Učenička evaluacija nastave likovne kulture «, Život i škola, 61(1), str. 179-193.

Matijević, Milan; Drljača, Miroslav; Topolovčan, Tomislav (2016b), »Moje nastavne aktivnosti u nastavi likovne kulture«, Učenje i nastava, 2(1), str. 129-150.

Montessori, Maria (1988), The Montessori Method, New York: Schocken Books.

Mullen, Jil; Wolff, Kate (2018), Engaging the arts in the broader education policy landscape. Education trends, Denver: Education Commission of the States (USA), p. 8. ERIC Number: ED591735

Nkem, Udeani; Femi, Kayode (2018). »Evaluation of the goals of art education programme in the Northeast, Nigeria«, International Journal of Education and Practice, 6(2), str. 76-83. doi: https://doi.org/10.18488/journal.61.2018.62.76.83

Philipps Reichherzer, Silvija (2003), Montessori priprema za život: odgoj neovisnosti i odgovornosti, Jastrebarsko: Naklada Slap.

Rajović, Ranko (2013), IQ djeteta - briga roditelja: za predškolski uzrast: MENSA - NTC sistem učenja, Zagreb: Hrvatska MENSA.

Rajović, Ranko (2017), Kako igrom uspješno razvijati djetetov IQ, Split: Harfa.

Rosenberg-Lee, Miriam (2018), »Training studies: An experimental design to advance educational neuroscience «, Mind, Brain, and Education, 12(1), str. 12-22. EJ1184817. doi: https://doi.org/10.1111/mbe.12166

Sanal, Mustafa; Ozen, Fatmanur (2018), »The quest for qoality in teacher education in Turkey: The abrogation of teacher programs from secondary educa- 
tion«, European Journal of Educational Research, 7(3), str. 539-554. doi: https://doi.org/10.12973/eu-jer.7.3.539

Seitz, Marielle; Hallwachs, Ursula (1977), Montessori ili Waldorf, Zagreb: Educa.

Skiera, Ehrenhard (2010), Reformpädagogik in Geschichte und Gegenwart: Eine kritische Einführung, München: Oldenburg Verlag. doi: https://doi. org/10.1524/9783486851328

Steiner, Rudolf (1995a), Odgoj djeteta s gledišta duhovne znanosti, Zagreb: Društvo za waldorfsku pedagogiju Hrvatske.

Steiner, Rudolf (1995b), Pedagoška osnova i ciljevi Waldorfske škole, Zagreb: Društvo za waldorfsku pedagogiju Hrvatske.

Steiner, Rudolf (2019), Erziehung zum Menschen: wissen wir Erwachsene, was in unseren Kindern wirklich lebt?, ein Geschenk für Eltern, Lehrer und alle, die Kinder lieben, Leipzig; Frankfurt am Main: Deutsche Nationalbibliothek.

Šarančić, Snježana (2014), »Dobrobiti likovnog stvaralaštva«, Napredak, 154(12), str. 91-104.

Topolovčan, Tomislav; Rajić, Višnja; Matijević, Milan (2017), Konstruktivistička nastava: teorija i empirijska istraživanja, Zagreb: Učiteljski fakultet Sveučilišta u Zagrebu.

Wiel, Angelika (ur.) (2019), Kindheit in der Waldorfpädagogik, Weinheim: Beltz Juventa.

\title{
EXAMINING THE INTEREST IN AND SATISFACTION WITH FINE ARTS TEACHING AS AN INCENTIVE TO DEVELOP LEARNING CAPABILITIES IN OTHER SUBJECTS
}

\author{
Miroslav D. Drljača, Siniša Opić, Milan Matijević
}

This research was carried out on a sample of third year pupils of vocational schools and gymnasiums $(N=605)$. Of the surveyed pupils, 253 of them attended gymnasiums, while 352 attended vocational secondary schools. The goal of this research was to examine specificities in secondary school pupils'perceptions of the importance of subjects in the field of the fine arts. A separate analysis was undertaken for only two selected dependent variables: the importance of subjects in the field of the fine arts for developing memory and the ability to learn other subjects, and interest in and satisfaction with participation in fine arts activities. The results show that there is no statistically significant difference between the estimation of gymnasium and vocational school pupils regarding participation in fine arts activities or in their estimation of the importance of fine arts activities in developing memory and the ability to learn other subjects. There is a statistically significant gender difference in the estimation of participation in fine arts activities, as well 
as in the estimation of the importance of fine arts activities in developing memory and the ability to learn other subjects. It can be concluded that respondents were unable to estimate how much or why they would use competencies gained in fine arts teaching in their continued education or their future careers.

Key words: gymnasium, vocational school, fine arts, fine arts teaching, interest in fine arts activities, satisfaction with fine arts teaching 